\title{
Focal myositis associated with Leishmania spp. infection in a dog - diagnostic approach
}

\section{Bruna Gonzalez dos Santos ${ }^{*}$ (1) Maria Lígia de Arruda Mestieri ${ }^{1,2}$ (i) Mauren Picada Emanuelli (i) $^{2}$ Tainã Normanton Guim ${ }^{2}$ (i) Jennifer Stello Minuzzi ${ }^{2}$ (i) Eduarda Costa Lamberti ${ }^{2}$ (i)}

${ }^{1}$ Programa de Pós-graduação em Ciência Animal (PPGCA), Universidade Federal do Pampa (UNIPAMPA), 97501-970, Uruguaiana, RS, Brasil. E-mail: brunagonzalez96@gmail.com *Corresponding author.

${ }^{2}$ Programa de Residência Integrada em Medicina Veterinária (PRIMV), Universidade Federal do Pampa (UNIPAMPA), Uruguaiana, RS, Brasil.

ABSTRACT: Canine visceral leishmaniasis is a systemic, zoonotic disease widely spread in several countries. The disease is caused by Leishmania spp., and the dog is the main reservoir of this parasite. Clinical signs in the muscle skeletal system consist of muscle atrophy, weakness, lameness, abnormal locomotion, osteitis, polyarthritis, heat and swelling of the joints, enlarged local lymph nodes and pain. In this note, a case of canine myositis of the lumbar region associated with Leishmania spp. infection is reported. Clinical signs included weakness, fever, mild dehydration, enlarged mandibular, pre-scapular and popliteal lymph nodes and a large palpable soft mass in the lumbar region, semiadhered and not painful. Serologic diagnosis resulted reagent by indirect immunofluorescence reaction method. Findings of ultrasonography of the lower back are described, revealing the misalignment of muscle fibers, interspersed with anechoic areas compatible with edema. Local fine needle aspiration cytology was crucial for a definitive diagnosis, revealing amastigote forms. In endemic areas of leishmaniasis, clinicians should consider this disease as a differential diagnosis in the presence of musculoskeletal injuries with no apparent cause.

Key words: Leishmania spp., leishmaniasis, dog, skeletal muscle disorder, fine needle aspiration cytology.

Miosite focal associada à infecção por Leishmania spp. em um cão-abordagem diagnóstica

RESUMO: A leishmaniose canina visceral é uma doença sistêmica, zoonótica e amplamente difundida causada por parasitas do gênero Leishmania spp., sendo o cão importante hospedeiro. Os sinais clínicos de leishmaniose no sistema músculo esquelético se constituem em atrofia muscular, fraqueza, claudicação, locomoção anormal, osteite, poliartrite, hipertermia, dor e edema das articulações. A presente nota descreve um caso de miosite lombar em cão associada à infecção por Leishmania spp. Os sinais clínicos incluíram fraqueza, febre, desidratação leve, aumento dos linfonodos mandibulares, pré-escapulares e poplíteos e uma grande massa macia palpável na região lombar, semi-aderida e não dolorosa. O diagnóstico sorológico resultou em reagente pelo método da reação de imunofluorescência indireta totalmente diluída. Os achados da ultrassonografia da região lombar são descritos, revelando o desalinhamento das fibras musculares, intercaladas com áreas anecóicas, compatíveis com edema. A citologia local de aspiração por agulha fina foi crucial para o diagnóstico definitivo, revelando formas amastigotas. Nas áreas endêmicas da leishmaniose, deve-se considerar esta doença como diagnóstico diferencial na presença de lesões musculoesqueléticas sem causa aparente.

Palavras-chave: Leishmania spp., leishmaniose, canino, injúria muscular, citologia.

Canine visceral leishmaniasis $(\mathrm{CVL})$ is a systemic, widely spread zoonotic disease caused by Leishmania spp. (BLAVIER et al., 2001). The $\operatorname{dog}$ is the main reservoir host of this parasite, that is transmitted via vectors from Lutzomyia longipalpis. (KASZAK et al., 2015). The diagnosis of CVL is complex, with nonspecific clinical signs and confusing clinicopathological abnormalities (SOLANO-GALLEGO et al., 2017).

Clinical signs in dogs often include weight loss, depression, cutaneous lesions, lymphadenomegaly, splenomegaly, ocular lesions and epistaxis (BLUME et al., 2019). Clinical signs in the muscle skeletal system consist of muscle atrophy, weakness, lameness, abnormal locomotion, osteitis, polyarthritis, heat and swelling of the joints, enlarged local lymph nodes and pain being the most common osteoarticular sign "abnormal locomotion" (BLAVIER et al., 2001).

In dogs, generalized and focal forms of inflammatory myopathies have been reported, with etiologies ranging from immune-mediated disorder 
(polymyositis) to infectious forms (protozoan, rickettsia, spirochetes, viral, fungal and other bacteria) and neoplasms (EVANS et al., 2014). Although rarely reported in the literature, it is possible to occur in dogs associated with Leishmania infantum infection (PACIELLO et al., 2009).

The diagnosis of myositis is based on clinical signs including muscle weakness, gait, muscular atrophy, palpable granulomatous lesions and eventually areas of swelling with soft consistency within normal portions of muscle (BLAVIER et al., 2001). Other non-specific findings are high serum creatine kinase (CK) concentration and abnormal electromyography (EMG). Additional diagnostic tests such as fine needle aspiration cytology (FNA), biopsy, ultrasonography and magnetic resonance (MR) imaging are available to further evaluation of musculoskeletal lesions (PODELL, 2002).

The aim of this report is to describe a case of lumbar myositis in a dog caused by Leishmania infection, highlighting this disease as a relevant differential diagnosis in cases of muscle skeletal disorders in dogs from endemics areas.

A 2-years-old female French Bulldog, born and living at Paso de Los Libres city, state of
Corrientes, Argentina, weighing 9,8 kg was referred at the University Veterinary Hospital (HuVet) from University of Pampa (UNIPAMPA) at Uruguaiana city, state of Rio Grande do Sul, Brazil. Paso de Los Libres is a city bordering Uruguaiana, both cities are endemic for canine visceral leishmaniasis. The patient had history of weakness, fever and a large mass in the lower back for 30 days, which worsened after treatment with corticoid. On physical examination, mild dehydration, enlarged mandibular, pre-scapular and popliteal lymph nodes, and a palpable soft mass in the lumbar region was found, about $5 \mathrm{~cm}$ in diameter, semi-adhered and not painful.

Blood was collected for serologic diagnosis of canine leishmaniasis (enzyme-linked immunosorbent assay method), which yielded nonreactive results for canine IgG leishmaniasis (Biogene kit). Therefore, a new material collection was performed and a fully diluted indirect immunofluorescence reaction method was performed, which resulted reagent 1:640 (reagent reference value equal to or greater than 1:40) (FUNDEP kit - Leishmaniasis Laboratory ICB / UFMG).

To evaluate the lumbar disorder, ultrasonography using linear transducer with $12 \mathrm{MHz}$ was performed (Figure 1). The images showed loss of muscle fiber pattern, presence of anechoic material (liquid)

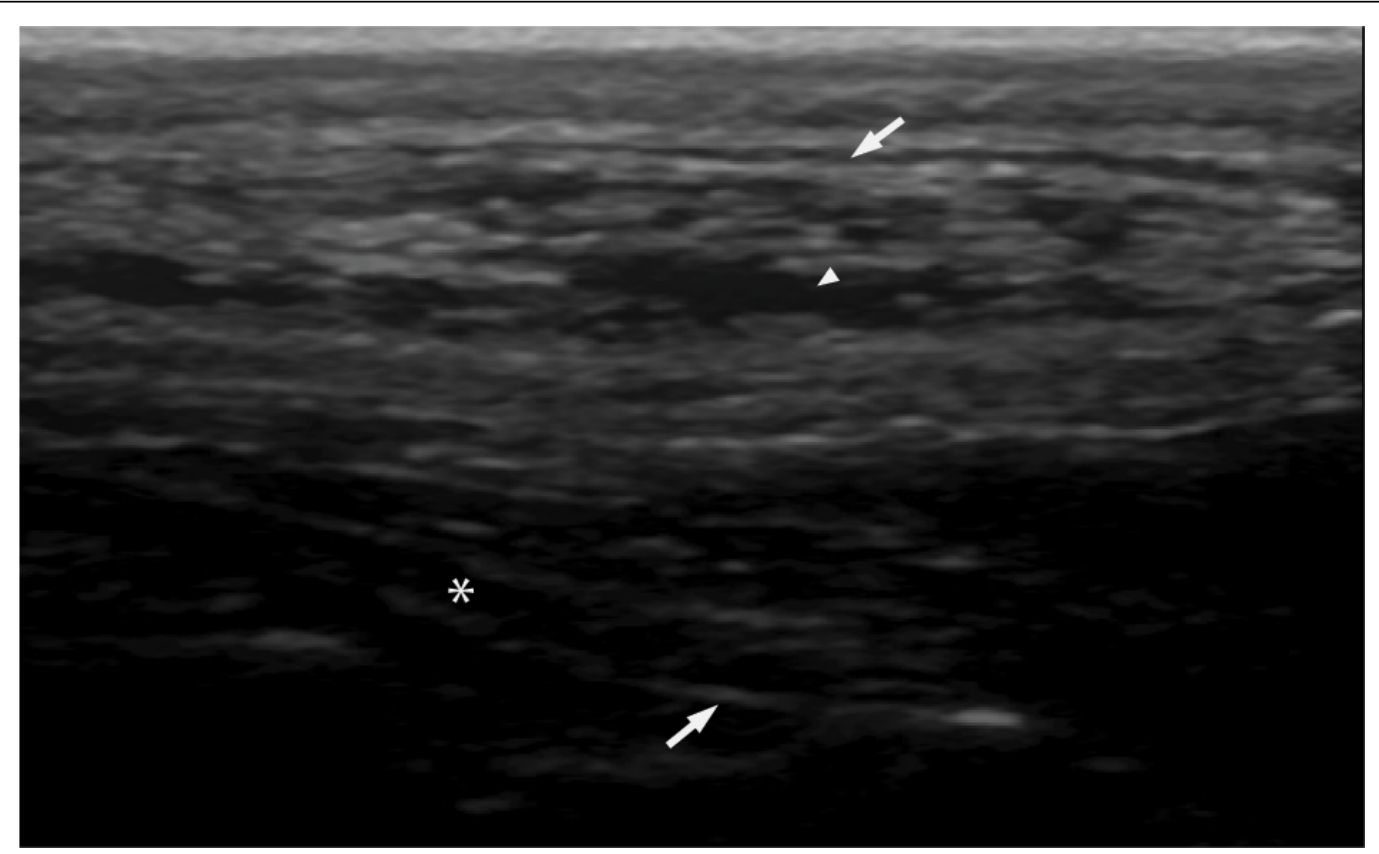

Figure 1 - Ultrasonographic image of the lower back musculature of the dog. Muscle can be limited by superficial and deeper fascia (solid arrows). Muscle fibers discontinuity is observed, interspersed with anechoic areas compatible with edema (arrow head); normal skeletal muscle structure is seen deeper to this change (asterisks).

Ciência Rural, v.51, n.2, 2021. 
interspersed into muscle fibers, suggesting inflammatory process, localized infection (abscess) or hematoma.

FNA was performed for cytologic examination. Slides were prepared using the squash technique, air dried and stained with Diff-Quik ${ }^{\circledR}$ (Differential Stain Set, American Scientific Products). Cytopathologic report described inflammation characterized by large number of neutrophils and reactive macrophages (Figure 2A), some phagocytic macrophages containing numerous structures round to elongated, with a round and peripheral nucleus, and a kinetoplast close to it. These structures were morphologically compatible with the amastigote forms of Leishmania spp. (Figure 2B). Cytologic interpretation was marked pyogranulomatous inflammation with intracellular organisms compatible with Leishmania spp.

FNA cytology is an important diagnostic tool to elucidate the etiology of the muscle injury (BLAVIER et al., 2001), confirming myositis caused by Leishmania spp. infection in this case. Cytology was also useful to exclude other causes of muscle mass such as linfomas (BLAVIER et al., 2001). Although amastigotes forms have been previously described in various types of tissue such as bone marrow, liver, spleen (LIMA et al., 2019; MOMO et al., 2014; MOREIRA et al., 2016), no reports of FNA muscle cytology for the diagnosis of Leishmania spp. infection have been found.

The pathogenesis of muscular injuries associated with canine visceral leishmaniasis is not completely enlightened. According to Gomes et al. (2012) there is a multifactorial mechanism contribution, including cellular, humoral immune responses and direct muscular injury caused by the parasite. It is believed that CVL also induces autoantibody production and can cause polymyositis, affecting mainly the appendicular musculature and causing progressive muscular weakness and atrophy, lameness, and exercise intolerance (KOUTINAS; KOUTINAS, 2014).

Dogs with CVL and polymyositis usually show generalized lesions and muscle atrophy (GOMES et al., 2012). Degeneration, necrosis and variation in size of muscle fibers can be seen in histopathological exams (GOMES et al., 2012; PACIELLO et al., 2009; VAMVAKIDIS et al., 2000). According to Gomes et al. (2012), microscopic muscular damage is commonly observed in dogs naturally infected by Leishmania spp., however clinical manifestations are rare. As multiple muscle biopsies were not performed in this patient, it is not possible to affirm if the inflammatory process was affecting other muscular groups. Clinically, only focal signs were noticed.

Yet subclinical, there are a few clinical cases of polimyositis already reported (PACIELLO et al., 2009; VAMVAKIDIS et al., 2000). In a study of ultrasonography in acute inflammatory myopathies, there were presence of lower echogenicity and a muscle edema pattern (ADLER; GAROFALO, 2009), such as observed in the present report. Therefore, it is
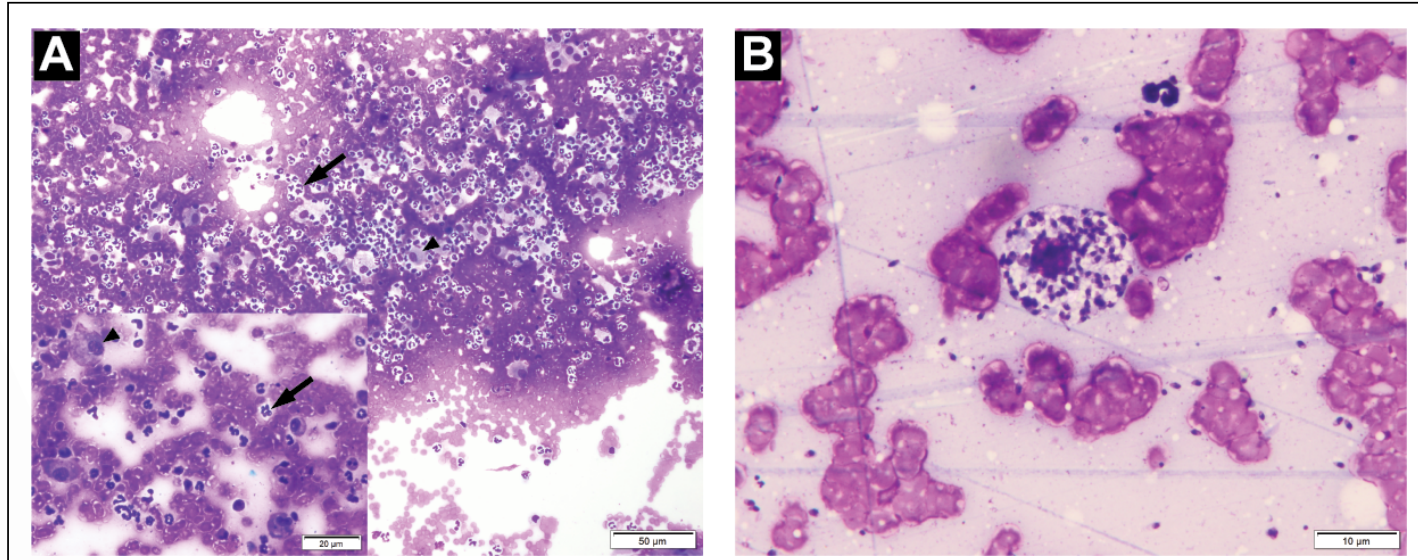

Figure 2 - FNA cytologic sample of a muscle mass from a dog. A) Marked pyogranulomatous inflammation characterized by large number of neutrophils (solid arrows) and reactive macrophages (arrows head). B) A phagocytic macrophage with intracellular organisms compatible with the amastigote forms of Leishmania spp. (center). Diff-Quik stain. Magnification: (A) 200x, inset 400x; (B) 1000x. 
important to highlight the ultrasonographic appearance and direct parasitological diagnoses in this case.

Focal myositis is a rare clinical condition in dogs. Clinicians should be aware of Leishmania spp. as an etiologic agent of myositis in dogs, especially in endemic regions.

\section{ACKNOWLEDGEMENTS}

This study was financed in part by the Coordenação de Aperfeiçoamento de Pessoal de Nível Superior (CAPES), Brasil - Finance code 001

\section{DECLARATION OF CONFLICT OF INTERESTS}

The authors declare no conflicts of interest. The founding sponsors played no role in the design of the study, collection, analyses, or interpretation of data, writing of the manuscript, or in the decision to publish the results.

\section{AUTHORS' CONTRIBUTIONS}

BS contributed to all steps, including data collection and drafting the manuscript; MM supervised and contributed to all steps, including drafting the manuscript and critical revision; TG and ME contributed to critical revision and cytologic diagnosis; JM was responsible for the clinical examination and outcome; EL was responsible for the ultrasound examination. All authors critically revised the manuscript and approved of the final version.

\section{REFERENCES}

ADLER, S.; GAROFALO, G. Ultrasound in the evaluation of the inflammatory myopathies. In: Kagen L. (eds) The Inflammatory Myopathies. Humana Press, pp 147-164, 2009. Available from: $<$ https://dx.doi.org/10.1007/978-1-60327-827-0_9>. Accessed: Feb. 03, 2020.

BLAVIER, A. et al. Atypical forms of Canine Leishmaniasis. The Veterinary Journal, [s. 1.], n. Table I, p.108-120, 2001. Available from: <http://www.idealibrary.com>. Accessed: Dec. 14, 2019. doi: $10.1053 /$ tvj1.2000.0556.

BLUME, G. R. et al. Oral lesions in dogs with Visceral Leishmaniasis. Journal of Comparative Pathology, [s. 1.], v.171, p.6-11, 2019. Available from: <https://doi.org/10.1016/j. jcpa.2019.06.006>. Accessed: Dec. 14, 2019. doi: 10.1016/j. jcpa.2019.06.006.

EVANS, J. et al. Canine inflammatory Myopathies: A clincopathologic Review of 200 Cases. Journal of Veterinary Internal Medicine, [s.1.], v.18, p.679-691, 2014. Available from: <https://www.ncbi.nlm.nih.gov/ pubmed/15515585>. Accessed: Dec. 12, 2019. doi: 10.1892/0891-6640(2004)18<679: cimacr $>2.0$.co;2.
GOMES, A. et al. Subclinical muscle injuries in dogs infected with Leishmania (Leishmania) infantum chagasi. Brazilian Journal of Veterinary Pathology, 5(3), 108-115, 2012. Available from: $<$ https://bjvp.org.br/wp-content/uploads/2015/07/DOWNLOADFULL-ARTICLE-24-20881_2012_11_30_40_58.pdf>. Accessed: May, 20, 2020.

KASZAK, I. et al. Review articles canine leishmaniasis - an emerging disease. Annals of Parasitology. [s. 1.], v.61, n.2, p.69-76, 2015. Available from: <https://www.ncbi.nlm.nih.gov/ pubmed/26342500\#>. Accessed: Dec. 12, 2019.

KOUTINAS, A. F.; KOUTINAS, C. K. Pathologic mechanisms underlying the clinical findings in canine leishmaniasis due to Leishmania infantum/chagasi. Veterinary Pathology, [s.1.], v.51, n.2, p.527-38, 2014. Available from: <http://vet. sagepub.com/content $/ 51 / 2 / 527>$. Accessed: Jan. 23, 2020. doi: $10.1177 / 0300985814521248$.

LIMA, I. et al. Assessment of histological liver alterations in dogs naturally infected with Leishmania infantum. Parasites \& Vectors, [s.1.], p.1-14, 2019. Available from: <https://doi.org/10.1186/ s13071-019-3723-1>. Accessed: Jan. 24, 2020. doi: 10.1186/ s13071-019-3723-1.

MOMO, C. et al. Morphological changes in the Bone Marrow of the Dogs with Visceral Leishmaniasis. Veterinary Medicine International, [s.1.], v.2014, 2014. Available from: $<$ https://www. ncbi.nlm.nih.gov/pubmed/24744957>. Accessed: Jan. 24, 2020. doi: $10.1155 / 2014 / 150582$.

MOREIRA, P. et al. Influence of apoptosis on liver and spleen resistance in dogs with visceral leishmaniasis. Brazilian Veterinary Journal of Parasitology, [s.1.], v.2961, p.341-347, 2016. Available from: <http://dx.doi.org/10.1590/S1984-29612016054>. Accessed: Jan. 30, 2020. doi: 10.1590/S1984-29612016054.

PACIELLO, O. et al. Canine inflammatory myopathy associated with Leishmania Infantum infection. Neuromuscular Disorders, [s.1.], v.19, n.2, p.124-130, 2009. Available from: <http://dx.doi. org/10.1016/j.nmd.2008.10.013>. Accessed: Jan. 30, 2020. doi: 10.1016/j.nmd.2008.10.013.

PODELL, M. Inflammatory myopathies. Neuromuscular diseases, [s.1.], v.32, n.1, p.147-167, 2002. Available from: <https://doi. org/10.1016/S0195-5616(03)00083-4>. Accessed: Feb. 18, 2020. doi: 10.1016/S0195-5616(03)00083-4.

SOLANO-GALLEGO, L. et al. Diagnostic challenges in the Era of Canine Leishmania infantum Vaccines. Trends in Parasitology, [s.1.], v.xx, p.1-12, 2017. Available from: <http://dx.doi. org/10.1016/j.pt.2017.06.004>. Accessed: Feb. 18, 2020. doi: 10.1016/j.pt.2017.06.004.

VAMVAKIDIS, C. D. et al. Masticatory and skeletal muscle myositis in canine leishmaniasis ( Leishmania infantum ). Veterinary Record, [s.1.], p.698-703, 2000. Available from: $<$ http://citeseerx.ist.psu.edu/viewdoc/download?doi=10.1.1.9 $05.3856 \&$ rep $=$ rep $1 \&$ type $=p d f>$. Accessed: Feb. 18, 2020. doi: 10.1.1.905.3856. 